\title{
Richard Bauckham
}

\section{The Christian World Around the New Testament}

\section{Collected Essays II}

[Die Christliche Welt und das Neue Testament. Gesammelte Aufsätze II.]

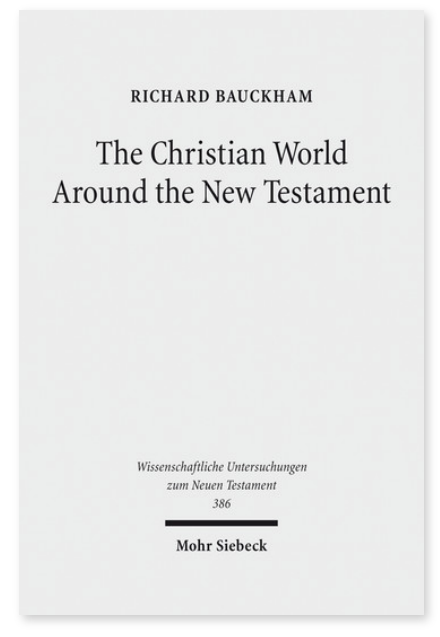

2017. X, 757 Seiten. WUNT I 386

ISBN 978-3-16-155462-9

DOI 10.1628/978-3-16-155462-9

eBook PDF 299,00€

ISBN 978-3-16-153305-1

Leinen $299,00 €$
Veröffentlicht auf Englisch.

Dieser Band versammelt 31 Aufsätze von Richard Bauckham, einem bekannten Neutestamentler, von denen die meisten bereits in Zeitschriften oder Sammelbänden veröffentlicht wurden. Er deckt viele Aspekte des frühen Christentums im neuen Testament und frühen patristischen Zeiten ab. Die hauptsächlichen Themen beinhalten das Publikum und die Überlieferung des Evangeliums, apokryphe christliche Literatur und die Menschen im frühen Christentum. Diese Sammlung reflektiert die Überzeugung des Verfassers, dass die historische Untersuchung des frühen Christentums die neutestamentliche Literatur nicht isoliert von anderer frühchristlicher Literatur betrachten sollte, sondern solche Quellen wie die apostolischen Väter und die christliche apokryphe Literatur ebenso in Betracht ziehen muss.

Richard Bauckham Born 1946; 1973 PhD, University of Cambridge; 1992-2007 Professor of New Testament Studies, St Andrews University, Scotland; 1998 elected Fellow of the British Academy; 2002 elected Fellow of the Royal Society of Edinburgh; since 2007 Emeritus Professor, St Andrews University, and Senior Scholar, Ridley Hall, Cambridge.
Jetzt bestellen:

https://mohrsiebeck.com/buch/the-christian-world-around-the-new-testament-9783161554629?no_cache=1 order@mohrsiebeck.com

Telefon: +49 (0)7071-923-17

Telefax: $+49(0) 7071-51104$ 